\title{
An Exploratory Analysis of Judicial Elections in Texas: Does Subject Matter Jurisdiction Matter?
}

\author{
Billy Monroe ${ }^{1}$, Nathan K. Mitchell ${ }^{1} \&$ Lee Payne $^{2}$ \\ ${ }^{1}$ Prairie View A\&M University, Prairie View, Texas, USA \\ ${ }^{2}$ Stephen F. Austin State University, Nacogdoches, Texas, USA \\ Correspondence: Billy Monroe, Division of Social Work, Behavioral and Political Sciences, P.O. Box 519; MS \\ 2203, Prairie View, TX 77446-2203, USA. Tel: 1-936-261-3200. E-mail: bwmonroe@pvamu.edu
}

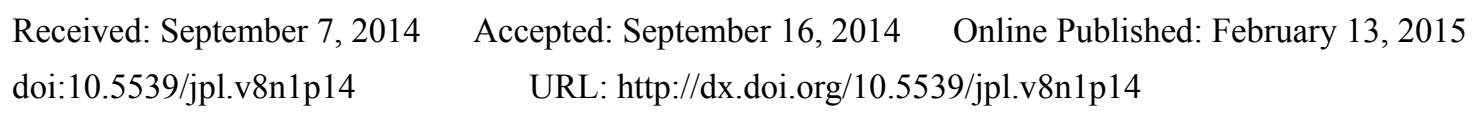

\begin{abstract}
The existence of both the Texas Supreme Court and Texas Court of Criminal Appeals makes it possible to test several important hypotheses of elections held between 1988 and 2008 using a variety of statistical tools related to the impact that subject matter jurisdiction (civil versus criminal) has on the outcomes of an election. In this comparative analysis, this article shows that the factors that influence election outcomes for seats on one court are different than those factors that influence outcomes on the other. New information is learned about the importance of demographic variables, judicial or legislative experience, and performance in the state bar poll.
\end{abstract}

Keywords: judicial elections, Texas court of criminal appeals, Texas supreme court, subject matter jurisdiction

\section{Introduction}

Hall \& Bonneau's $(2006 ; 2009)$ work on money and partisanship in state judicial elections has sparked debate on which other variables should be included in analytical models of judicial selection. In general, judicial elections are important to study, because the candidate pools are so specialized, it is hard to determine if traditional measures of candidate quality are really important to models of success. One important question that is somewhat unaddressed in this area is whether or not subject matter jurisdiction influences the politics of selection. This study will examine the case of Texas. Texas is one of two states with two courts of last resort, meaning that two entities occupy the space of supreme judicial review in the state - the Texas Court of Criminal Appeals and the Texas Supreme Court. Champagne \& Cheek (2005) suggest that these courts are very different culturally, as well as politically, and that the Supreme Court occupies a special place in Texas politics with regards to the amount of money, interest group activity, and media attention. Because of these factors, the way in which the judges are elected is going to be impacted by the differing roles of the two top courts.

This exploratory analysis builds on the theoretical models of Champagne \& Cheek (2005) to generate new hypotheses regarding the impact of subject matter jurisdiction on the election of justices. Their models include independent variables for party identification, campaign financing, race, gender, and incumbency. Using a controlled comparison of key factors, this study will add variables to account for candidate background or quality (previous judicial experience and previous experience in either the legislative or executive branches) and candidate support in the state bar poll. This study seeks to determine which variables matter in terms of judicial success. The main hypothesis of this study is that variables that measure candidate quality, like financing, will matter more in the Supreme Court than in the Court of Criminal Appeals, because of the Supreme Court's unique relationship with the media and public opinion. The Texas Supreme Court is more visible to the public and the campaigns attract more attention from interest groups (leading to much more money being raised and spent compared to elections for the Court of Criminal Appeals). This case study is important, because it can help scholars to understand judicial elections as a whole and develop hypotheses to test in other states or countries with similar judicial arrangements. Only two U.S. states (Texas and Oklahoma) separate their courts of last resort by subject matter and this separation allows for an experimental design where the importance of campaign financing can be tested and controlled for. Controlling for money allows for the ability to see the importance of the other explanatory variables mentioned above.

Due to a lower sample size of races and missing data on important key variables, we opt to utilize a series of 
bivariate correlations and tests of statistical significance instead of a more sophisticated modeling strategy. Ideally, we would want to utilize a multivariate model to provide a more robust test of statistical significance, but the finer grained data were not available for specific indicators leading to some modeling problems. Some of the most logical variables to include in the model did not have the information accessible - especially for the Texas Court of Criminal Appeals in particular and for both courts in general during the late 1980s and early 1990s. Background information was especially challenging for the earlier years. For example, it was not always possible to know if a candidate has 5 years or 20 years of previous judicial experience but it was possible to know exactly which candidates had judicial experience and which ones did not. Due to these concerns, the lower powered tests were used.

This article is meant to be an extended research note to explore the relationships between key variables and the likelihood of winning judicial elections. Through a controlled comparison of the top two courts in Texas, this study will explore two questions. The first is which variables matter the most in explaining judicial elections outcomes in Texas and the second is whether or not these variables are different depending on the type of court. The goal of this study is to provide a starting place for additional analysis as finer grained data become available and to provide a starting place to explore cases like Oklahoma with a similar judicial structure.

\subsection{The Case of Texas}

As stated earlier, Texas was selected for the study because it is the only state other than Oklahoma to have separate courts of last resort for criminal and civil jurisdictions. Oklahoma, however, uses a merit system for judicial selection, which leaves Texas as the only state to use partisan elections to select judges for separate civil and criminal courts of last resort - making Texas a worthy case study. All other states using elections for judicial selection have a court structure in which a single court of last resort has unified civil and criminal jurisdiction. Both Texas courts have nine members who serve staggered six year terms (Hall \& Bonneau, 2009).

The Texas Supreme Court has jurisdiction over civil matters affecting monetary interests while the Court of Criminal Appeals has jurisdiction over criminal matters affecting liberty interests. The separation of jurisdiction for the courts of last resort permits the study of differences in selection politics in the same system using partisan elections to select judges. The Texas Supreme Court provides an example of the new era in judicial elections characterized by extensive funding, increased interest group participation, and greater media attention than in the past. In contrast, the elections for the Texas Court of Criminal Appeals retain elements traditionally associated with judicial elections such as low voter turnout and voter reliance on party identification and incumbency because of low information availability. Like most elections (judicial or otherwise), party identification and incumbency will still be important factors in Texas Supreme Court elections but the increased financing, interest group activity, and media attention will add a new dynamic that is just not seen in Texas Court of Criminal Appeals elections. That new dynamic is driven by the difference in jurisdiction. Interest groups are willing to spend money and compete for victories in areas of civil jurisdiction, such as tort reform. The same level of interest and competition cannot be found in criminal cases on an empirical level (Champagne \& Cheek, 2005; Monroe, 2008). The study also serves as a baseline for research comparing judicial selection politics across selection systems such as the comparison of Texas with Oklahoma that uses a merit system for the selection of judges in future research.

\section{Judicial Elections: An Overview and Discussion of Important Variables}

The states use various methods to select judges to serve in the court system. Some states use an appointment system with the governor selecting judges and often requiring the consent of the legislature. In some rare situations, the legislature may also directly appoint judges. Other states use a partisan or non-partisan election to select judges. Several states use a merit system, which combines the appointment and election approaches by allowing the governor to appoint a judge for an initial term after a screening process with the voters deciding if the judge should be returned to the bench at the expiration of the term (Hall \& Bonneau, 2009). Eighty-seven percent of state judges face a contestable election, with the majority of states using either an election or a merit system (Schotland, 2003).

Partisanship is always an important variable for judicial elections. Baum (1987) found that voters in partisan judicial elections tend to vote based on party affiliation because of uncertainty about the qualifications of judges. These findings were subsequently corroborated, with ballot information (especially party affiliation), serving as the main cue for voters when they did not have sufficient information about candidates from other sources (Klein \& Baum, 2001) Judicial elections have traditionally been characterized by few contested positions and strong incumbency advantages. As a result, there was little need for extensive campaigns and financing, with candidates for judicial positions required only to discuss their qualifications. The Canons of Judicial Ethics also prohibited 
candidates from discussing their position on issues that could come before them if they were elected, which is known as the "announce clause". The Supreme Court decision in Republican Party of Minnesota v. White, 536 U.S. 765 (2002) altered the judicial electoral process by declaring the announce clause a violation of the judicial candidate's First Amendment rights to freedom of speech that could be abridged only if the state could demonstrate a compelling interest for the restriction (American Judicature Society, 2007). It is likely to accelerate the trend towards what Schotland (2002) calls "nastier, noisier, and costlier" modern judicial elections.

The importance of partisanship is also manifested by the level of straight ticket voting. In 2004, fifty-five percent of Republicans and forty-five percent of Democrats voted straight tickets in Texas elections (Mack, 2006). The level of uncertainty for voters that Baum discussed seems to be diminishing in recent years because Hall and Bonneau (2006) found that experienced challengers for judicial seats, however, enjoy a higher rate of success against incumbents with the electorate apparently considering the qualifications of the candidate in making their voting decisions.

As discussed previously, campaign financing is also a significant variable influencing judicial elections, with the amounts spent on campaigns in Texas among the highest in the nation (Champagne, 2003; Schotland, 2001). Spending by candidates and special interest groups in all states with judicial elections dramatically increased in recent years (Bonneau, 2005; Hall \& Bonneau, 2009). A positive correlation has also been found between spending on judicial campaigns and citizen participation rates in state supreme court elections regardless of whether the balloting was partisan or non-partisan (Hall \& Bonneau 2008). It should also be noted that research has identified a correlation between campaign contributions and judicial decisions in Texas courts, with judges voting conservatively on landmark cases and in cases in the months prior to an election (McCall \& McCall, 2007).

The next logical variable would be candidate quality. Hall and Bonneau (2006) indicated that quality is related to experience, with both appointed and elected judges generally having extensive experience on the bench or in the legal profession. Surprisingly, the literature does not suggest other proxy measures for candidate quality and experience seems like the best measure logically (compared to something like law school attended, etc.) It is important to note that an empirical study examining the quality of judges has found no difference between appointed and elected judges but that study is relatively old (Glick, 1978). Incumbency is another variable affecting judicial elections and is related to experience. While incumbents enjoy an advantage in elections because of name recognition and generally more campaign financing, partisan elections result in a higher rate of defeat for incumbents than non-partisan or retention elections (Hall, 2001).

Whether or not the candidate was an ethnic minority would also seem to be an important variable. A study examining the issue of minority representation among the judges in state courts, however, found no differences between the percentages of minorities elected to the bench and the percentage of minorities appointed to the bench (Alozie, 1990), so it will be interesting to see if that holds in a state as diverse as Texas. Hurwitz and Lanier (2001) found that only 5.9 percent of all judges sitting on state benches were Black, 2.8 percent were Hispanic and 1.1 percent were Asian-and-Pacific-American. Women made up only about a quarter of the state judiciaries. In the Texas judiciary in 2000, only 15 percent of judges identified themselves as other than Caucasian (Champagne, 2003). Previous research has not extensively investigated the reasons the minority percentages of the judiciary are below the general percentage of minorities in the population. One possible cause may be low percentages of minority lawyers, which reduces the pool of experienced individuals qualified to serve on the bench (Wynn \& Mazur, 2004).

The final factor of interest is interest group participation. The trend in recent elections shows a movement towards more extensive financing and campaigning by judges because of interest group involvement, which could reduce the impartiality of the judiciary when a matter involves a campaign supporter (Champagne \& Cheek, 2002). The interest groups themselves also provide large amounts of money to candidates and extensively campaign for the ones they want to be elected so the degree of interest group support or opposition to a candidate should be considered an important explanatory variable in determining election outcomes (Champagne, 2001). Lawyers and their firms are often some of the most active interest groups in trying to sway elections through their campaigning and spending money. Judicial candidates often use a strong performance in the bar poll as a springboard for important endorsements from newspapers or other interested observers. The state bar poll can be seen as a measurement of the perspectives of its members in the legal profession regarding the quality of the candidates and can also serve as an informational cue to voters in certain circumstances (Hanssen, 2004). The candidates can also enjoy the benefits of gaining more public support by using their performance in the poll as part of their campaign strategy and find more people willing to contribute money. Other interest groups might publish voter information guides, provide an endorsement, or simply campaign on a 
candidate's behalf (including campaign financing).

\section{Methodology and Design}

This study uses comparative methodology to compare two courts of last resort that exist within the same state of Texas. As such, the culture, history, and political environments of the state are all controlled, increasing the validity of any claims offered by this study. This type of study approximates Mill's method of difference, because the one factor that is different between the two courts is the types of cases they address. If there are differences between the variables that influence elections outcomes it would be due to the difference in the subject matter of the cases and not other factors. This study employs a unique dataset of general and primary elections returns from 1988 - 2008 in which biographical data, campaign finance data, and political institution data are combined. Over 371 elections are included, with 176 unique candidates are included in the study. Table 1 shows the specific independent variables used in the study. The dependent variable of interest is the outcome of the election.

Table 1. Summary statistics for judicial election data $(1988-2008)$

\begin{tabular}{lccccc}
\hline Variables of Interest & $\boldsymbol{N}$ & Mean & Std. Dev. & Min & Max \\
\hline Election Result $(1,0)$ & 371 & 0.345 & 0.476 & 0 & 1 \\
Republican Party $(1,0)$ & 371 & 0.563 & 0.497 & 0 & 1 \\
Female $(1,0)$ & 371 & 0.205 & 0.404 & 0 & 1 \\
African American $(1,0)$ & 371 & 0.0297 & 0.170 & 0 & 1 \\
Hispanic/Latino $(1,0)$ & 371 & 0.539 & 0.226 & 0 & 1 \\
Incumbent $(1,0)$ & 371 & 0.248 & 0.432 & 0 & 1 \\
Supreme Court Race $(1,0)$ & 371 & 0.456 & 0.499 & 0 & 1 \\
Judicial Experience $(1,0)$ & 371 & 0.593 & 0.492 & 0 & 1 \\
Legislative/Exec Experience (1,0) & 371 & 0.348 & 0.477 & 0 & 1 \\
State Bar Poll Percentage & 371 & 27.6 & 21.6 & 0 & 100 \\
Campaign Contributions $(\$ 10,000$ 's) & 371 & 15.3 & 31.4 & 0 & 270 \\
Campaign Expenditures (\$10,000’s) & 371 & 15.3 & 32.7 & 0 & 253 \\
\hline
\end{tabular}

The data used in the study were limited to the judicial election campaigns between 1988 and 2008 in the state of Texas. A potential limitation in the research methodology is the relatively small sample size that encompasses only 20 years of judicial election data, but this span of time was the time with the greatest amount of available data. The year 1988 was selected for the beginning of the period under investigation because it marked the end of Democrat dominance of Texas judicial elections. For a brief period, both parties were comparatively strong in judicial elections, followed by Republican dominance until the present. Data prior to 1988 is not available for some variables, such as campaign financing. Basic biographical and background data was challenging for all time periods for candidates that were not the frontrunners, but this study includes important biographical factors that other studies of judicial elections have not. The time frame covers the best group of candidates that were available given the availability of the data. This study improves on the previous models by Cheek and Champagne (2005) by including factors related to incumbency, experience, race, gender, and performance in the state bar poll in addition to political party and campaign financing. The other important addition to the Cheek and Champagne (2005) study is the inclusion of the Court of Criminal Appeals candidate data.

The campaign finance variables were taken from the National Institute on Money in State Politics. The Institute is a nonpartisan 501(c)(3) organization that catalogs state and local campaign finance information and collects information on judicial races. The Institute is funded from private public interest charities, charitable donations, and contract work with its database. All data from the Institute is publically available through its website and application programming interface (API) system or through bulk download. Reports from the Texas Ethics Commission were also used when necessary. Contributions and expenditures are both measured in this study and though they are correlated, influence different parts of the candidacy process. Contributions can serve the purpose of intimidating potential challengers. In addition, contributions are not inherently equivalent to expenditures because the candidate may use personal funds for campaign finance, which is common in low-cost 
campaigns for the Texas Court of Criminal Appeals elections. Candidates may also receive contributions substantially in excess of their expenditures, with the candidate able to conserve the excess contributions for campaigns in future election cycles. Expenditures are often presumed to be more effective in explaining the outcome of elections because the direct impact of a campaign financing advantage can be seen through how much money is being spent (advertising, etc.), but including contributions is also worthwhile for the reasons stated above. Independently testing their influence is important and this study tries to accomplish this.

The role of party identification cannot be underestimated since it is likely to have an impact throughout the model, given the usual one party dominance of Texas. Party may also have an interactive effect with other key variables. Party identification has a particularly strong effect on campaign financing because the amount of funds raised and spent by each candidate is at least partially contingent on the degree of support for each party in an election. Incumbency and state bar polling advantages have similar significant interactive effects with the other variables as well. Further detail will be provided at the appropriate juncture in the analysis section. Party identification was easy to determine, given that Texas uses partisan elections. The information was gathered from the Texas Secretary of State's website and their catalog of election returns.

The best measure available for interest group participation in Texas was through the use of the state bar poll, which is a measure of the level of support a candidate enjoys within the legal community and is tabulated in a nonpartisan fashion. Since not all groups are involved in the same way and with the same level of impact as the state bar - the bar poll was chosen as the best measure for interest group activity for this study. The results of the poll can be found in the Texas Bar Journal. The poll is published in February of each election year before that year's primary election so that it can be a nonpartisan exercise and is not considered an endorsement from the publication.

\section{Results}

The first step in this exploratory analysis is to examine the bivariate correlations between the above independent variables and whether or not a candidate won. Cross tabulations were used to explore descriptive trends, while basic measures of association and tests of statistical significance were used to assess impact. For the categorical data, gamma was used to determine the strength of the relationship and a chi ${ }^{2}$ test was used to determine statistical significance. Gamma is also a proportional reduction in error statistic, which indicates how much a variable helps reduce errors in "guessing" distributions of the dependent variable, in this case whether or not a candidate won the election or not. As this study is exploratory in nature, we do not make a priori assumptions about what differences should exist between the two types of courts. Descriptively, the two courts are different. Table 2 highlights some of the unique characteristics of the elections for each court. 
Table 2. Summary statistics from each court $(1988-2008)$

\begin{tabular}{|c|c|c|}
\hline & $\begin{array}{c}\text { Texas Supreme Court General } \\
\text { Elections }\end{array}$ & $\begin{array}{c}\text { Texas Court of Criminal Appeals General } \\
\text { Elections }\end{array}$ \\
\hline Uncontested Races & 2 Uncontested (both Republican) & 1 Uncontested (Democrat) \\
\hline Min. Contested Races & $\begin{array}{l}5 \text { Minimally Contested (4 Republican, } \\
1 \text { Democrat) }\end{array}$ & $\begin{array}{l}6 \text { Minimally Contested (4 Republican, } 2 \\
\text { Democrat) }\end{array}$ \\
\hline Contested Races & $\begin{array}{l}27 \text { Contested by Both Parties ( } 27 \\
\text { Republican, } 27 \text { Democrat) }\end{array}$ & $\begin{array}{l}22 \text { Contested by Both Parties ( } 22 \\
\text { Republican, } 22 \text { Democrat) }\end{array}$ \\
\hline Total Races & Total: 33 Republican, 28 Democrat & Total: 26 Republican 25 Democrat \\
\hline Women Candidates & $\begin{array}{l}12 \text { Women (6 Republican, } 6 \\
\text { Democrat) }\end{array}$ & 9 Women (8 Republican 1 Democrat) \\
\hline African American & 2 African American (both Republican) & $\begin{array}{l}3 \text { African American (1 Republican, } 2 \\
\text { Democrat) }\end{array}$ \\
\hline Hispanic/Latino & $\begin{array}{l}5 \text { Hispanic (1 Republican, } 4 \\
\text { Democrat) }\end{array}$ & 3 Hispanics (all Democrat) \\
\hline Incumbents & $\begin{array}{l}27 \text { incumbents (21 Republican, } 6 \\
\text { Democrat) }\end{array}$ & $\begin{array}{l}20 \text { incumbents (9 Republican, } 11 \\
\text { Democrat) }\end{array}$ \\
\hline State Bar Percentage & $\begin{array}{l}\text { Avg. State Bar Poll \%: } 41.9 \\
\text { (Republican Avg. 48.7, Democrat } \\
\text { Avg. 34.0) }\end{array}$ & $\begin{array}{l}\text { Avg. State Bar Poll \%: } 30.8 \text { (Republican } \\
\text { Avg. 25.7, Democrat Avg. 36.2) }\end{array}$ \\
\hline Contributions & $\begin{array}{l}\text { Avg. Contributions: } \$ 387,731 \\
\text { (Republican Avg. } \$ 451,514 \text {, Democrat } \\
\text { Avg. } \$ 299,763 \text { ) }\end{array}$ & $\begin{array}{l}\text { Avg. Contributions: } \$ 24,249 \text { (Republican } \\
\text { Avg. } \$ 16,590 \text { Democrat Avg. } \$ 30,791 \text { ) }\end{array}$ \\
\hline Expenditures & $\begin{array}{l}\text { Avg. Expenditures: } \$ 474,123 \\
\text { (Republican Avg. } \$ 566,347 \text {, Democrat } \\
\text { Avg. } \$ 365,430 \text { ) }\end{array}$ & $\begin{array}{l}\text { Avg. Expenditures: } \$ 30,193 \text { (Republican } \\
\text { Avg. } \$ 19,324 \text {, Democrat Avg. } \$ 41,496 \text { ) }\end{array}$ \\
\hline
\end{tabular}

The level of competition for both courts is about the same. Around 84 percent of all races were contested and more than one party ran for office. The level of diversity was the same as well. While objectively more women ran in the general elections of the Supreme Court, both courts had about the same percentage of African Americans and Latinos. The incumbency rate was a bit higher in the Texas Supreme Court with 27 incumbents running under the time period of this study. The biggest difference that stands out is the amount of money spent on the judicial races. The average contributions for the Texas Supreme Court candidates were $\$ 387,721$, while the average contributions for the Texas Court of Criminal Appeals candidates were \$24,249. Expenditures were also very high with $\$ 474,123$ for the Texas Supreme Court and $\$ 30,193$ for the Texas Court of Criminal Appeals.

These are significant issues that should be explored more systematically. Below, we discuss some of the descriptive trends. Cross tabulations and difference of means tests are included in the appendix to this report. Tests of statistical significance and measures of association will be featured in Table 3 below. Gamma was used as a proportional reduction in error (PRE) test which measures the impact of a specific factor on reducing error in guessing an outcome or dependent variable. $\mathrm{Chi}^{2}$ is used to determine if the differences in distributions observed in the cross tabulations are statistically significant. For the continuous data, Pearson's $\mathrm{R}$ and $\mathrm{t}$ - tests were used to determine strength of association and statistical significance. 
Table 3. Measures of Association (Gamma / Pearson's r) and Tests of Significance (Chi ${ }^{2}$ ) / T Tests

\begin{tabular}{lllll}
\hline & \multicolumn{3}{c}{ Texas Supreme Court } & \multicolumn{2}{c}{ Texas Court of Criminal Appeals } \\
\hline Republican Party & Gamma $=0 . .390$ & $\mathrm{Chi}^{2}=5.740^{*}$ & Gamma $=0.127$ & $\mathrm{Chi}^{2}=0.713$ \\
Female & Gamma $=0.182$ & $\mathrm{Chi}^{2}=0.821$ & Gamma $=0.159$ & $\mathrm{Chi}^{2}=0.837$ \\
African American & Gamma $=0.587$ & $\mathrm{Chi}^{2}=2.406$ & Gamma $=0.784$ & $\mathrm{Chi}^{2}=5.079^{*}$ \\
Hispanic/Latino & $\mathrm{Gamma}=-1.000$ & $\mathrm{Chi}^{2}=6.233^{* *}$ & Gamma $=-1.000$ & $\mathrm{Chi}^{2}=3.972^{*}$ \\
Incumbent & Gamma $=0.401$ & $\mathrm{Chi}^{2}=5.871^{*}$ & Gamma $=0.837$ & $\mathrm{Chi}^{2}=37.421^{* *}$ \\
Judicial Experience & Gamma $=0.423$ & $\mathrm{Chi}^{2}=4.533^{*}$ & Gamma $=0 . .558$ & $\mathrm{Chi}^{2}=17.919^{* *}$ \\
Legislative/Exec. Exp. & $\mathrm{Gamma}=0.598$ & $\mathrm{Chi}^{2}=11.012^{* *}$ & $\mathrm{Gamma}=0.210$ & $\mathrm{Chi}^{2}=2.171$ \\
State Bar Poll \% & $\mathrm{r}=0.285$ & $\mathrm{t}=7.104^{* *}$ & $\mathrm{r}=0.440$ & $\mathrm{t}=3.847^{* *}$ \\
Campaign Contributions & $\mathrm{r}=0.159$ & $\mathrm{t}=2.083^{*}$ & $\mathrm{r}=0.211$ & $\mathrm{t}=3.052^{* *}$ \\
Campaign Expenditures. & $\mathrm{r}=0.154$ & $\mathrm{t}=2.011^{*}$ & $\mathrm{r}=0.134$ & $\mathrm{t}=1.94^{*}$ \\
\hline
\end{tabular}

Note: $*=\mathrm{P}<0.05 \quad * * \mathrm{P}<0.001$

\subsection{Political Party}

Political party was only a significant factor in the case of the Texas Supreme Court. A cross tabulation of the elections for the Texas Supreme Court, 65 percent of the winners were Republicans, whereas only 35 percent of the winners were Democrats. The gamma statistic of 0.394 indicates a moderate or weak relationship and that knowing the party of the candidate improves our predictions by about 40 percent. A chi ${ }^{2}$ statistic of 5.74 indicates that the impact of political party is a statistically significant one. In the Court of Criminal Appeals, Democrats were as equally likely to win or lose, though the trend was in support of the Republican Party. As the Texas Supreme Court is more visible to voters, party remained an important predictor in winning. If you were a member of the dominat party at the time, you tended to do well.

The elections were very competitive in the late 1980s and early 1990s, but the Republicans have dominated since then. The Republicans won the vast majority of seats, but the Democrats were certainly able to hold their own during the brief period when they were competitive, winning seven races. Seven victories are a surprisingly high number considering how few seats are up for election every two years (three on average) and because the Democrats were only competitive for the first four to six years of a twenty year study.

\subsection{Candidate Ethnicity and Gender}

Candidate ethnicity and gender are other important factors to consider for a variety of reasons discussed above. The cross tabulations and descriptive analyses provided some interesting results. Gender was not a statistically significant factor in determining the electoral success of a candidate in either race, which was unexpected. The data show that women were equally as likely to win either type of court. Being an African American produced statistically significant chi ${ }^{2}$ values in the case of the Court of Criminal Appeals, but not the Texas Supreme Court. The gamma statistic of 0.784 can interpreted as reducing the error in predictions about the dependent variable by about 78 percent. It is important to note is that there were very few African American candidates who won or were even involved in races. Only about six percent of the winners in the Court of Criminal Appeals were African American. Whether or not the candidate was Latino or of Hispanic ethnicity was statistically significant for both the Texas Supreme Court and the Court of Criminal Appeals. Given that zero Hispanics or Latinos won their judicial races, knowing the ethnicity reduced the error in the prediction by 100 percent. The best indicator of minority success was political party - candidates tended to win if they were members of the dominant party and lose if they were not.

\subsection{Candidate Quality}

Candidate quality is frequently a variable of interest in studies of elections. This study examines incumbency status, previous experience as a judge or a legislator, and campaign expenditures / contributions as measures of candidate quality. In the case of both the Texas Supreme Court and the Texas Court of Criminal Appeals, incumbency was an important variable. The chi ${ }^{2}$ statistics are significant, meaning that incumbency produces a meaningful impact in the election outcomes. Around 45 percent of the candidates who won at the Supreme Court were incumbents and 41 percent of the winning candidates for the Court of Criminal Appeals were incumbents. The gamma statistic for the Texas Supreme Court was lower than the Court of Criminal Appeals. Incumbency 
reduced the error in prediction by 80 percent in Court of Criminal Appeals and by 40 percent in the Supreme Court. It should also be noted that there were not as many incumbents as one would expect because several either chose to not run for reelection or ran for higher office. The best example is John Cornyn - a member of the Texas Supreme Court during the time period and is now a U.S. Senator.

Experience matters in winning judicial elections. Around 67 percent of the candidates who won elections to the Texas Court of Criminal Appeals had previously been a judge, whereas 84 percent of the winning candidates for the Texas Supreme Court had previous judicial experience. The chi ${ }^{2}$ tests revealed that the impact of judicial experience was statistically significant in election outcomes. The gamma scores revealed that judicial experience can reduce error in predictions of electoral success by 56 percent in the Court of Criminal Appeals and 43 percent in the Texas Supreme Court. The variable measuring previous legislative or executive branch experience was only had a statistically significant impact in the case of the Texas Supreme Court. Around 31 percent of the candidates who won election to the Texas Supreme Court had previous experience as a legislator or in the executive branch. The gamma score of 0.60 indicates a moderate relationship and that knowing a candidate's background in this area reduces the error in our predictions of candidate success by 60 percent. There is some question about why legislative or executive branch experience matters for the Texas Supreme Court and not the Court of Criminal Appeals. Previous connections from the executive branch or the legislative branch may prove helpful in running for the Supreme Court. Since those races are more expensive, candidates may need access to those networks to get ahead in the polls. This was one of the more surprising results because candidates for the Texas Court of Criminal Appeals were expected to be the ones likely to have past legislative or, more likely, executive experience as district attorneys or criminal prosecutors.

In the data presented in this article, money contributed and spent were important factors in winning. As these variables were continuous and interval/ratio data, difference of means tests was conducted to determine if winners or losers had different average contribution or expenditures rates. There were statistically significant differences between the average amount of money raised and the average amount of money spent by candidates who won and those who did not. Regardless of chamber, the effect was statistically significant, but candidates to the Texas Supreme Court raised more money and spent far more money than candidates for the Court of Criminal Appeals. To measure the effect size of the interval / ratio data, a Pearson's correlation was conducted. This produces a statistical indicator measuring how closely related to concepts are. The $r$ score for the Texas Supreme Court was 0.159 and the $r$ score for the Texas Court of Criminal Appeals was 0.211, meaning that a relationship is present but weak to moderate. The correlations for expenditures were a little lower. The $\mathrm{r}$ score for the Texas Supreme Court was 0.154 and the $r$ score for the Court of Criminal Appeals was 0.134. Money was important for both courts, but the magnitude of the money spent favored the Supreme Court.

Campaign financing clearly had a decisive role as the candidates who raised and spent more money relative to their given opponents won twenty-nine out of the thirty-four applicable elections to the Texas Supreme Court for example. The candidates who failed to win with this advantage were almost all involved during the years where the Republican takeover was taking effect and the higher campaign financing was unable to counter the strong effects of party identification. As mentioned before, contributions can serve the purpose of scaring off potential challengers or be saved for future election cycles. Logic would also tell you that expenditures have even more tangible dividends for candidates (more campaign advertisements, higher name recognition, etc.). Party identification, or more specifically party support among the voters, is often highly correlated with the campaign financing variables. When the two parties are relatively even in strength, campaign financing is usually close to equal as well. Campaign financing advantages occur when one party dominance is evident. The Republican Party was clearly dominant for much of the time period studied, so it is very possible that the campaign finance advantage was caused by the party's dominance in winning elections. Of course, the argument can just as easily be made that the campaign financing advantage led the Republicans to so many electoral victories. The Republicans clearly had the advantage in campaign financing in most races as well. In the case of Texas, it is likely that the voters' shift to the Republican Party that culminated in 1994 created a domino effect in terms of money that allowed the Republicans to continue their electoral success.

\subsection{Interest Group Activity and Bar Support}

The variable measuring interest group activity and community involvement was the state bar poll percentage. In both the Supreme Court and the Court of Criminal Appeals, winning candidates had a higher average vote than losing candidates and these differences were statistically significant according to the t-test. The average vote percent for winners in Supreme Court elections was 45 percent, whereas the average vote percent for the winners of elections to the Court of Criminal Appeals was 31 percent. In terms of correlations, the $\mathrm{r}$ score for the Supreme Court was 0.285 and the $r$ score for the Court of Criminal Appeals was 0.440, meaning that interest 
group activity was more closely related to winning in the Court of Criminal Appeals.

The cross tabulations also show just how reliable the state bar poll served as a predictor of election outcomes the candidate with a better showing won twenty-eight of the thirty-four elections (eighty-two percent). The candidate's vote percentage in the state bar polls shows a certain level of support within the state bar. The most direct impact of the bar poll on a campaign is that the results are publicized frequently so that it has the effect of adding legitimacy to the candidate in terms of newspaper endorsements and other advertisements. These endorsements and ads can only strengthen the candidate's chances of winning the election.

It is much more difficult to determine what might lead to a candidate's popularity within the state bar and legal community. Many factors may influence performance in the state bar poll - incumbency, campaign financing, and even party identification. Party identification influences the poll indirectly because the results are nonpartisan but at least some members of the bar are highly involved in political activities. The argument can be made that the bar poll provides further evidence of the importance of party support because segments of the state bar are well-known for supporting one major party over the other in Texas (plaintiffs' lawyers are heavily Democratic while civil defense lawyers favor Republicans), so even though the poll is nonpartisan in nature, the results often have a partisan feel to them. The problem is that the data collected is unable to support that argument and there is no data readily available that can. The only definitive conclusion is that candidates that do well in this nonpartisan poll of the legal community also have a higher likelihood of winning elections, due in part to the fact that the legal community generally serves as one of the most active special interest group in judicial politics. Performing well likely also has the effect of increasing campaign contributions.

\section{Conclusion and Discussion}

This set of data makes it possible to see patterns in these election outcomes and the results will lead to hypotheses that will be tested with more sophisticated statistical methods. Simply looking at the election results from 1988-2008 will lead to the obvious conclusion that party identification retains its traditional role in judicial elections so the real impact comes from the other variables included in the study. The role of campaign financing is certainly different for the two courts. Much more money is involved in Supreme Court races, but having more money than your opponent is an advantage in any circumstance. Candidates who are at a disadvantage in terms of campaign financing do have a better chance at winning an election for the Court of Criminal Appeals, but it is helpful to be a member of the right party if money is a problem. In this case - two strikes mean you are out. The same can be said for minority candidates. Party affiliation went a long way in determining election success or failure for women and other minority candidates. In terms of future research possibilities, it is very possible that minority candidates would have even more success in primary elections, where the role of party identification is nullified. The results here are also a very positive sign for the Democratic Party as they become a more competitive party in Texas, especially with the changing of demographics in the voting population. The incumbency advantage is still present since incumbents were very successful when present, especially in the later years of this time period. A more powerful second party may change that as well. It is also clear that both parties value high quality candidates, who are well-qualified. Elections are the hallmark of judicial accountability so the parties are making more than token efforts to make that possible rather than having the Democrats running weak candidates because they see no other choice due to the current Republican dominance. Judicial experience is definitely more important than legislative or executive experience, which mirrors the federal judiciary in that regard. The most surprising result, mostly because its importance has never really tested, is the role of the state bar poll. The lawyers of this state have been one of the most active special interest groups in judicial elections in terms of campaign financing and educating the public about the candidates they support so it was a natural decision to attempt to measure their influence on elections for the two courts of last resort. The bar is much more active on the Supreme Court side rather than the Court of Criminal Appeals because they decide issues involving money instead of issues of liberty. Tort reform has always seemed to be more controversial and newsworthy in Texas rather than issues like the death penalty. The bar poll is not a perfect measure since it is relatively indirect and limited in its meaning. It requires the candidates to attempt to publicize this level of support and transform it into endorsements or advertisements to the public that this independent group of legal professionals believes that they are worthy of winning the election. One fact; however, is clear - the results of the bar poll are a reliable indicator in determining election outcomes.

Partisanship and campaign financing obviously cause conflicts of interest, real or perceived, for members of the Texas Supreme Court and Court of Criminal Appeals. The election mechanism does guarantee accountability and they are much more competitive than they might appear, considering the dominance of the Republican Party in recent years. Obviously, any broad generalizations must be met with a word of caution because the study only encompasses twenty years from only one state and more intense study is required. The argument can easily be 
made that it would be very practical to combine these two courts into one high court that handles both civil and criminal jurisdictions without adding too much money or interest group activity into the election process. There is simply not enough money or interest in the Court of Criminal Appeals (for either the public or the legal community) to believe that the selection process would be greatly affected. Of course, this is far from a new idea. A more significant reform possibility is to move from partisan elections to nonpartisan elections. The reform movement has had limited momentum in Texas since the 1980s with only incremental success because there is has been no real urgency for change from either the Texas citizenry or elected officials for most of the time period. The elimination of party (and at least some of the money) would have a great impact on judicial elections, and still maintain the ability of the public to hold their judges accountable through the election process.

\section{References}

Alozie, N. (1990). Distribution of women and minority judges: The effects of judicial selection models. Social Science Quarterly, 71(315).

American Judicature Society. (2007). Developments following Republican Party of Minnesota v. White, 536 U.S. 765 (2002). American Judicature Society. Retrieved from http://www.ajs.org

Baum, L. (1987). Information and party voting in 'semi-partisan' judicial elections. Political Behavior, 9(1), 62-74. http://dx.doi.org/10.1007/BF00987279

Bonneau, C. W. (2005). What price justice(s)? Understanding campaign spending in state supreme court $\begin{array}{lllll}\text { elections. State Politics and Policy } & \text { Quarterly, }\end{array}$ http://dx.doi.org/10.1177/153244000500500201

Champagne, A. (2001). Interest groups and judicial elections. Loyola of Los Angeles Law Review, 34, 1391-1409.

Champagne, A. (2003). The politics of judicial selection. Policy Studies Journal, 31(3), 413-419. http://dx.doi.org/10.1111/1541-0072.00031

Champagne, A., \& Cheek, K. (2002). The cycle of judicial elections: Texas as a case study. Fordham Urban Law Journal, 29(3), 907-927.

Champagne, A., \& Cheek, K. (2005). Judicial politics in Texas: Partisanship, money, and politics in state courts. New York, NY: Peter Lang Publishing Inc.

Glick, H. R. (1978.) The promise and the performance of the Missouri Plan: Judicial selection in the fifty states. University of Miami Law Review, 32(3), 509-541.

Hall, M. G. (2001). Voluntary retirements from state supreme courts: Assessing democratic pressures to relinquish the bench. Journal of Politics, 63(2), 1112-1140.

Hall, M. G., \& Bonneau, C. (2006). Does quality matter? Challenges in state supreme court elections. American Journal of Political Science, 50(1), 20-33. http://dx.doi.org/10.1111/j.1540-5907.2006.00167.x

Hall, M. G., \& Bonneau, C. (2008). Mobilizing interest: The effects of money on citizen participation in state supreme court elections. American Journal of Political Science, 52(July), 457-470. http://dx.doi.org/10.1111/j.1540-5907.2008.00323.x

Hall, M. G., \& Bonneau, C. (2009). In defense of judicial elections (Controversies in electoral democracy and representation). New York, NY: Routledge.

Hanssen, F. A. (2004). Learning about judicial independence: Institutional change in the state courts. The Journal of Legal Studies, 33(June), 1391-1409.

Hurwitz, M. S., \& Lanier, D. (2001). Women and minorities on state and federal appellate benches, 1985 and 1999. Judicature, 85(September-October), 84-92.

Klein, D., \& Baum, L. (2001). Ballot information and voting decisions in judicial elections. Political Research Quarterly, 50(4), 709-728. http://dx.doi.org/10.1177/106591290105400402

Mack, K. (2006, October 13). Straight-ticket voters urged to change ways. Houston Chronicle. Retrieved from http://www.chron.com

McCall, M. M., \& McCall, M. (2007). Campaign contributions, judicial decisions, and the Texas Supreme Court: Assessing the appearance of impropriety. Judicature, 90(5), 214-225.

Monroe, B. (2008). Judicial selection in Texas: A study of election outcomes 1988-2004 (Unpublished doctoral dissertation). University of Texas at Dallas, Richardson, Texas. 
Schotland, R. A. (2001). Financing judicial elections, 2000: Change and challenge. Law Review of Michigan State University Detroit College of Law 2001, 849-899.

Schotland, R. A. (2002). Republican party of Minnesota v. White: Should judges be more like politicians? Judges' Journal, 41, 7-10.

Schotland, R. A. (2003). 2002 judicial elections. Spectrum: The journal of state government, (Winter), 18-19.

Wynn, H. J. A., \& Mazur, E. P. (2004). Judicial diversity: Where independence and accountability meet. Albany Law Review, 67, 766-791.

\section{Appendix A}

Cross Tabulations and Difference of Means Tests

\begin{tabular}{lcccc}
\hline Political Party & \multicolumn{2}{c}{ Texas Supreme } & Court & \multicolumn{2}{c}{ Texas Court of Criminal Appeals } \\
& Lose & Win & Lose & Win \\
Democratic Party & $55 \%(66)$ & $35 \%(17)$ & $41 \%(51)$ & $35 \%(28)$ \\
Republican Party & $45 \%(54)$ & $65 \%(32)$ & $59 \%(72)$ & $65 \%(51)$ \\
& \multicolumn{2}{c}{ Texas Supreme Court } & & Texas Court of Criminal Appeals \\
Gender & Lose & Win & Lose & Win \\
Male Candidate & $82 \%(98)$ & $76 \%(37)$ & $81 \%(100)$ & $75 \%(60)$ \\
Female Candidate & $18 \%(22)$ & $24 \%(12)$ & $19 \%(21)$ & $24 \%(19)$ \\
& & & & \\
Incumbency & Texas Supreme Court & Texas Court of Criminal Appeals \\
Challenger & Lose & Win & Lose & Win \\
Incumbent & $74 \%(89)$ & $55 \%(27)$ & $94 \%(116)$ & $59 \%(47)$ \\
& $26 \%(31)$ & $45 \%(22)$ & $6 \%(7)$ & $41 \%(32)$
\end{tabular}

African American

Other Candidates

African American

Hispanic / Latino

Other Candidates

Hispanic / Latino

Judicial Exp.

No Judicial Exp.

Prev. Judicial Exp.

Pol. Experience

No Legis or Exec.

Legis or Exec.
Texas Supreme Court

$$
\text { Lose Win }
$$

98\% (118)

94\%(46)

$2 \%$

$6 \%(3)$

Texas Supreme Court

$\begin{array}{cc}\text { Lose } & \text { Win } \\ 88 \%(106) & 100 \%(49) \\ 12 \%(14) & 0 \%(0)\end{array}$

Texas Supreme Court

$$
\text { Lose }
$$

$33 \%(39)$

$67 \%(81)$

Win
$16 \%(8)$
$84 \%(41)$

Texas Supreme Court

$$
\text { Lose }
$$

$90 \%(108)$

Win

$10 \%(12)$

$69 \%(34)$

$31 \%(15)$

Texas Court of Criminal Appeals

$$
\text { Lose Win }
$$

$99 \%(122)$

$94 \%(74)$

$1 \%(1)$

$6 \%(5)$

Texas Court of Criminal Appeals

Lose Win
$95 \%(117)$
$100 \%(79)$
$5 \%(6)$
$0 \%(0)$

Texas Court of Criminal Appeals

Lose Win

$\begin{array}{ll}63 \%(78) & 33 \%(26) \\ 37 \%(45) & 67 \%(53)\end{array}$

Texas Court of Criminal Appeals

$$
\text { Lose Win }
$$

$54 \%(66) \quad 43 \%(34)$

$46 \%(57) \quad 57 \%(45)$ 


\section{Appendix B}

Difference of Means Tests (t-test)

\begin{tabular}{|c|c|c|c|c|}
\hline \multirow[t]{2}{*}{ State Bar \% } & \multicolumn{2}{|c|}{ Texas Supreme Court } & \multicolumn{2}{|c|}{ Texas Court of Criminal Appeals } \\
\hline & Mean & $S E$ & Mean & $S E$ \\
\hline Lose & 29.733 & 2.291 & 16.206 & 0.920 \\
\hline Win & 45.412 & 3.027 & 31.158 & 2.204 \\
\hline Diff & -15.679 & 4.075 & -14.953 & 2.105 \\
\hline$t-$ Test & \multicolumn{2}{|c|}{$-3.848 * *(\mathrm{DF} 167)$} & \multicolumn{2}{|c|}{$-7.104 * *(\mathrm{DF}=200)$} \\
\hline \multirow[t]{2}{*}{ Contr. (\$10,000’s) } & \multicolumn{2}{|c|}{ Texas Supreme Court } & \multicolumn{2}{|c|}{ Texas Court of Criminal Appeals } \\
\hline & Mean & $S E$ & Mean & $S E$ \\
\hline Lose & 27.436 & 39.999 & 1.213 & 0.186 \\
\hline Win & 41.740 & 44.094 & 2.465 & 0.4224 \\
\hline Diff & -14.304 & 68.693 & -1.252 & 0.410 \\
\hline$t-$ Test & \multicolumn{2}{|c|}{$-2.082 *(\mathrm{DF}=167)$} & \multicolumn{2}{|c|}{$-3.0516^{* *}(\mathrm{DF}=200)$} \\
\hline \multirow[t]{2}{*}{ Expend.(\$10,000’s) } & \multicolumn{2}{|c|}{ Texas Supreme Court } & \multicolumn{2}{|c|}{ Texas Court of Criminal Appeals } \\
\hline & Mean & $S E$ & Mean & $S E$ \\
\hline Lose & 26.783 & 4.072 & 1.822 & 0.259 \\
\hline Win & 41.421 & 5.501 & 2.464 & 0.422 \\
\hline Diff & -14.638 & 7.281 & -1.252 & 0.410 \\
\hline$t-$ Test & \multicolumn{2}{|c|}{$-2.011 *(\mathrm{DF}=167)$} & \multicolumn{2}{|c|}{$-3.052(\mathrm{DF}=200)$} \\
\hline
\end{tabular}

\section{Copyrights}

Copyright for this article is retained by the author(s), with first publication rights granted to the journal.

This is an open-access article distributed under the terms and conditions of the Creative Commons Attribution license (http://creativecommons.org/licenses/by/3.0/). 